\title{
Effect of kushmandachurna (Benincasahispida Powder) in Prameha W.S.R. Type 2 Diabetes Mellitus
}

\author{
Dr. Shinde Bhagwat ${ }^{1}$, Dr. Ghawte Sanket Annasaheb ${ }^{2}$ \\ ${ }^{1}$ Principal , H.O.D. \& Professor Post Graduate Dept. of Kayachikitsa PMT’s Ayurved College, \\ ShevgaonDist -Ahemednagar - Maharashtra \\ ${ }^{2}$ P.G. in KayachikitsaPost Graduate Department of KayachikitsaAyurved College Shevgaon \\ Corresponding Author:-Dr. Bhagawat Tukaram Shinde \\ (Principal , H.O.D. \& Professor)Post Graduate Dept. of Kayachikitsa PMT's Ayurved College, \\ ShevgaonDist -Ahemednagar - Maharashtra
}

\begin{abstract}
:-
Background: Diabetes mellitus refers to group of common metabolic disorders that share the phenotype of hyperglycemia. In simple word, elevated sugar level in human body than normal. Around 347 million of total world population is diabetic and in 2012,1.5 million deaths happened due to diabetes. In Ayurveda ,Prameha (Diabetes) mentioned in CharakaSamhita, Sushrutasanhita, Madhavnidana, Vagbhata by Acharyas. In which disease ; frequency and quantity of urine more called Prameha. It can be correlated with Diabetes due to common symptoms like Bahumutrata (Polyurea), Trishna(Polydipsia) Mutraavilata(TurbidUrine) Sweda(Swating) Kshudhadhikya (Increased Appetite). The clinical features of Diabetes may present acutely, with the three classic symptoms of thirst, polyuria and weight loss; even so, clinical recognition may be delayed until the patient is seriously ill. KushmandaChurna is selected for their wide spectrum action on Prameha like Tridoshahara(BalencedTridosha) Anulomaka, Bastishodhaka, Balya
\end{abstract}

Aim: To evaluate the effect of KushmandaChurna in the treatment of Prameha.

Materials and Methods: Total 20 patients of Pramehaw.s.r. Type 2 DM with 4weeks duration were enrolled and randomly allocated to GroupA (Oral KushmandaChurna 6gm with Anupan Natural Honey 12gm daily twice), Group B (Oral KushmandaChurna 6gm with AnupanUshnodaka daily twice) . Duration of treatment was considered about 1 month. Blood sugar level, Urine sugar level, Nocturia (Urination during night), Turbid urine (MutaAvilata), observed at weekly interval.

Results: With the treatment of 4 weeks , Group A showed dramatic improvements in signs and symptoms. Resolution of Bahumutrata, Mutraavilata, Urine sugar post prandial occurred in about $80 \%$ of patients. Whereas $70 \%$ of patients having reduction in Blood sugar fasting, bold sugar post prandial and urine sugar fastin. In patients of Group B, Blood sugar fasting and post prandial shows good results in 50\%. Cessation of Bahumutrata, Urine sugar fasting \& post prandial occurred in $60 \%$, whereasMutraavilata reduced in $70 \%$. So use of Kushmandachurna with anupana as Natural honey or Usnodaka shows significant effect. But when compared before and after treatment by applying ' $t$ ' test to parameters, $p>0.001$ hence difference is not significant. Any treatment can use for Prameha

Conclusion: Kushamndachurna with natural honey or kushmandachurna with ushnodaka as anupana is useful for Prameha.

Key words: Prameha, Type 2 Diabetes Mellitus, KushmandaChurna , Natural Honey, Ushnodaka 


\section{Introduction: -}

According to World Health Organization (WHO) the term diabetes mellitus (DM) describes a metabolic disorder of. multipleaetiology characterized by chronic hyperglycaemia, with disturbances of carbohydrate, fat and protein metabolism, resulting from defects in insulin secretion, insulin action. ${ }^{1}$ Currently DM is most common and wide spread Metabolic disorders in the world ${ }^{3}$. In our Ayurveda Pramehacan correlate with Diabetes mellitus due to its similar characteristics.

In 2008, an estimated 347 million people in the world had diabetes and the prevalence is growing, particularly in low- and middle-income countries. ${ }^{2}$ India had 69.2 million people living with diabetes $(8.7 \%)$ as per the 2015 data $^{2}$. Of these, it remained undiagnosed in more than 36 million people ${ }^{4}$. Over time, high blood sugar can seriously compromise every major organ system in the body, causing heart attacks, strokes, nerve damage, kidney failure, blindness, impotence and infections that can lead to amputations ${ }^{5}$. Diabetes is treatable. Diabetes can be controlled and managed to prevent complications. Increasing access to diagnosis, self-management education and affordable treatment are vital components of the response. So good thing is that our Ayurveda has been given answer of Diabetes or Prameha before thousand years back; as almost all Acharya $^{6,7}$ described Diabetes Mellitus (Prameha) with miraculous treatment in details. Among that use of Kushmanda ${ }^{8}$ Churna is one of the best for Prameha.

\section{Aims \& Objectives -}

1. To study the efficacy of KushmandaChurna used in Type2 DM.

2. To study detail cause of Type2 DM.

3. To study various concepts of Prameha(Diabetes Mellitus) regarding causes \& treatments in Ayurveda.

4. To study the effectiveness of KushmandaChurna in Pramehaw.s.r. Diabetes Mellitus .

\section{Material \&Methodology :-}

It is simple, random group study with sample size 20. It was conducted on patients who were suffered from Type2 DM. Samples were selected randomly from Department of Kayachikitsa of ShriSantEknathRugnalaya, Shevgaon.

\section{Inclusion Criteria :-}

1. Patients were selected irrespective of religion, sex and occupation.

2. Age group 30 to 60 years

3. Post prandial blood sugar level is less than or equal to $200 \mathrm{mg} / \mathrm{dl}$

\section{Exclusion Criteria :-}

1. Unconscious, deaf and dumb patients.

2. Type 1 Diabetes Mellitus

3. Severe GI, liver, CVD diseases, pancreatitis, neuroendocrinaltumors, acute MI etc..

4. Having blood sugar level $>200 \mathrm{mg} / \mathrm{dl}$

\section{Methodology:-}

Thoroughly history had been taken regarding to sign and symptoms of patients. Selected patients were drawn into 2 groups e.g. Group A\& B.

Group A -10 patients were treated with KushmandaChurna with natural honey9 as anupan Group B - Whereas other 10 patients were administered with KushmandaChurna with Ushnodaka10 asanupan All treatment were done daily for 1 month. Assessment was done every 7 th day.

\section{Drug Administration:-}

Table No. 1 - Administration of Procedures

\begin{tabular}{|c|c|c|c|}
\hline Sr. No. & Topic & Group A & Group B \\
\hline $\mathbf{1}$ & Medicine & KushmandaChurna & KushmandaChurna \\
\hline $\mathbf{2}$ & Anupana & Natural Honey & Ushnodaka \\
\hline $\mathbf{3}$ & Dose & 6gm Churna +12 gm Honey & 6gm Churna \\
\hline
\end{tabular}


Dr. Shinde Bhagwat ${ }^{1}$, Inte rnational Journal of Ayurvedic\& Herbal Medicine 7(4) July.-Aug.2017 (2718-2723)

\begin{tabular}{|c|c|c|c|}
\hline $\mathbf{4}$ & Time & Just before Lunch \& Dinner & Just before Lunch \& Dinner \\
\hline $\mathbf{5}$ & Duration & 1 Month & 1 Month \\
\hline
\end{tabular}

\section{Follow Up :-}

There were five follow up performed for case study which included $1^{\text {st }}$ (Base line $), 2^{\text {nd }}\left(7^{\text {th }}\right.$ day $), 3^{\text {rd }}\left(14^{\text {th }}\right.$ day), $4^{\text {th }}\left(21^{\text {st }}\right.$ day) $\& 5^{\text {th }}\left(28^{\text {th }}\right.$ day $)$ follow ups.

\section{Assessment Criteria :-}

Table No.2- Gradation for signs and symptoms

\begin{tabular}{|c|c|c|c|c|c|c|c|}
\hline Sr No & Observation & Normal & Score & Borderline & Score & Abnormal & Score \\
\hline 1 & $\begin{array}{c}\text { Bahumutrata } \\
\text { (Urine Quntity) }\end{array}$ & $\begin{array}{c}5 \text { to } 6 \text { times } \\
\text { /day }\end{array}$ & 0 & $\begin{array}{c}7 \text { to } 8 \text { times } / \\
\text { day }\end{array}$ & $\begin{array}{c}9 \text { to } 10 \text { times } / \\
\text { day }\end{array}$ & 2 \\
\hline 2 & $\begin{array}{c}\text { Mutraavilata } \\
\text { Colour of urine) }\end{array}$ & $\begin{array}{c}\text { Medium } \\
\text { yellow }\end{array}$ & 0 & Colourless & 1 & Cloudy \\
\hline
\end{tabular}

Table No. 3 -Blood Sugar Level (BSL) Normal-Abnormal Fasting \& Post Prandial Values

\begin{tabular}{|r|c|c|c|c|c|}
\hline \multirow{2}{*}{ Sr.No } & \multicolumn{2}{|c|}{ BSL Fating Values(mg/dl) } & \multirow{2}{*}{$\begin{array}{c}\text { BSL Post Prandial } \\
\text { values (mg/dl) }\end{array}$} & Result & Score \\
\cline { 2 - 6 } & Minimum & Maximum & Less than 140 & Normal & 0 \\
\hline 1 & 70 & 100 & 140 to 200 & $\begin{array}{c}\text { Borderline or early } \\
\text { diabetes mellitus }\end{array}$ & 1 \\
\hline 3 & 101 & - & $>200$ & $\begin{array}{c}\text { Abnormal / Established } \\
\text { Diabetes Mellitus }\end{array}$ & 2 \\
\hline
\end{tabular}

Table No.4-Urine Sugar Fasting \& Post Prandial Presentation

\begin{tabular}{|c|l|c|c|}
\hline Sr no & Urine strip colour observation & Result & Score \\
\hline 1 & Light turquoise & Normal & 0 \\
\hline 2 & Light green & Trace & 1 \\
\hline 3 & Green & ++ & 1 \\
\hline 4 & Dark Yellow & +++ & 2 \\
\hline 5 & Light brown & ++++ & 2 \\
\hline 6 & Dark brown & & 2 \\
\hline
\end{tabular}

\section{Observations \& Results :-}

Before started the treatment, all patients of both groups had all signs and symptoms (mild to severe) which mentioned in Table no .2 in different manner like much or less. After treatment there was decreased in signs and symptoms of both groups had been seen. 
Dr. Shinde Bhagwat ${ }^{1}$, Inte rnational Journal of Ayurvedic\& Herbal Medicine 7(4) July.-Aug.2017 (2718-2723)

Table No 5 - Number of patients showing sings \& symptoms before treatment(BT) and after treatment(AT)

\begin{tabular}{|l|l|l|l|l|}
\hline & \multicolumn{2}{|c|}{ Group A } & \multicolumn{2}{c|}{ Group B } \\
\hline & B.T. & A.T. & B.T. & A.T. \\
\hline Bahumutrata(Urine Quntity) & $\mathbf{1 0}$ & $\mathbf{2}$ & $\mathbf{1 0}$ & $\mathbf{4}$ \\
\hline Mutraavilata(Colour of urine) & $\mathbf{1 0}$ & $\mathbf{2}$ & $\mathbf{1 0}$ & $\mathbf{3}$ \\
\hline Blood Sugar Fasting & $\mathbf{1 0}$ & $\mathbf{3}$ & $\mathbf{1 0}$ & $\mathbf{5}$ \\
\hline Blood Sugar Post Prandial & $\mathbf{1 0}$ & $\mathbf{3}$ & $\mathbf{1 0}$ & $\mathbf{5}$ \\
\hline Urine Sugar Fasting & $\mathbf{1 0}$ & $\mathbf{3}$ & $\mathbf{1 0}$ & $\mathbf{4}$ \\
\hline Urine Sugar Post Prandial & $\mathbf{1 0}$ & $\mathbf{2}$ & $\mathbf{1 0}$ & $\mathbf{4}$ \\
\hline
\end{tabular}

Table No 4-Group wise Improvements In Parameters After Treatments

\begin{tabular}{|l|l|l|l|l|l|l|l|}
\hline Group & \multirow{2}{*}{$\begin{array}{l}\text { Number } \\
\text { of Patient }\end{array}$} & \multicolumn{5}{|l|}{ Parameters } \\
\cline { 3 - 8 } & & Bahumutrata & Mutaavilata & $\begin{array}{l}\text { Blood Sugar } \\
\text { Fasting }\end{array}$ & $\begin{array}{l}\text { Blood Sugar } \\
\text { Post Prandial }\end{array}$ & $\begin{array}{l}\text { Urine Sugar } \\
\text { Fasting }\end{array}$ & $\begin{array}{l}\text { Urine Sugar Post } \\
\text { Prandial }\end{array}$ \\
\hline A & 10 & $08(80 \%)$ & $08(80 \%)$ & $07(70 \%)$ & $07(70 \%)$ & $07(70 \%)$ & $08(80 \%)$ \\
\hline B & 10 & $06(60 \%)$ & $07(70 \%)$ & $05(50 \%)$ & $05(50 \%)$ & $06(60 \%)$ & $06(60 \%)$ \\
\hline
\end{tabular}

\section{Statistical Analysis:-}

Paired ' $\mathrm{t}$ ' and unpaired ' $\mathrm{t}$ ' test is applied for analysis.

Table No. 5- Findings in Group A after $t / t$ by paired 't'test

\begin{tabular}{|l|l|l|l|l|l|l|}
\hline & Mean & $\sum(\mathrm{x}-\mathrm{x})^{2}$ & Std. Dev. & Std. Error & $\mathrm{t}_{9}$ & Result \\
\hline Bahumutrata & 1.3 & 4.1 & 0.225 & 0.0712 & 18.26 & \\
\hline Mutraavilata & 1.3 & 4.1 & 0.225 & 0.0712 & 18.26 \\
\hline Blood sugar Fasting & 1.1 & 5.4 & 0.2582 & 0.0816 & 13.48 & $\begin{array}{l}\text { As p }<0.001 \text { treatment } \\
\text { is highly significant }\end{array}$ \\
\hline Blood Sugar Post prandial & 1.1 & 5.4 & 0.2582 & 0.0816 & 13.48 & 13.48 \\
\hline Urine Sugar Fasting & 1.1 & 5.4 & 0.2582 & 0.0816 & 18.26 \\
\hline Urine Sugar Post prandial & 1.3 & 4.1 & 0.225 & 0.0712 & & \\
\hline
\end{tabular}

Table No.6- Findings in Group $B$ after $t / t$ by paired ' $t$ ' test

\begin{tabular}{|c|c|c|c|c|c|c|}
\hline & Mean & $\sum(\mathrm{x}-\mathrm{x})^{2}$ & Std. Dev. & Std. Error & $\mathrm{t}_{9}$ & Result \\
\hline Bahumutrata & 0.9 & 8.9 & 0.3315 & 0.1048 & 8.58 & \multirow{6}{*}{$\begin{array}{l}\text { As } p<0.001 \\
\text { treatment is } \\
\text { highly } \\
\text { significant }\end{array}$} \\
\hline Mutraavilata & 1.1 & 5.4 & 0.2582 & 0.0816 & 13.48 & \\
\hline Blood sugar Fasting & 0.8 & 5.6 & 0.263 & 0.0831 & 9.62 & \\
\hline Blood Sugar Post prandial & 0.8 & 5.6 & 0.263 & 0.0831 & 9.62 & \\
\hline Urine Sugar Fasting & 0.9 & 2.9 & 0.1892 & 0.06 & 15 & \\
\hline Urine Sugar Post prandial & 0.9 & 2.9 & 0.1892 & 0.06 & 15 & \\
\hline
\end{tabular}


Dr. Shinde Bhagwat ${ }^{1}$, Inte rnational Journal of Ayurvedic\& Herbal Medicine 7(4) July.-Aug.2017 (2718-2723)

Table No.7- Comparison of Group A\&B after treatment by unpaired ' $t$ ' test

\begin{tabular}{|c|c|c|c|c|}
\hline & Std. Dev. & Std. Error & $\overline{\mathbf{t}_{18}}$ & Result \\
\hline Bahumutrata & 2.5193 & 0.5039 & 0.7938 & \multirow{6}{*}{$\begin{array}{l}\text { As } p>0.001 \text { treatment is } \\
\text { not signific ant }\end{array}$} \\
\hline Mutraavilata & 2.3248 & 0.463 & 0.4319 & \\
\hline Blood sugar Fasting & 2.635 & 0.527 & 0.5693 & \\
\hline Blood Sugar Post prandial & 2.635 & 0.527 & 0.5693 & \\
\hline Urine Sugar Fasting & 2.485 & 0.497 & 0.4024 & \\
\hline Urine Sugar Post prandial & 2.186 & 0.4371 & 0.9151 & \\
\hline
\end{tabular}

When we compared treatment of 2 groups, for all symptoms $\mathrm{p}$ is greater than 0.001 , difference is not significant. Treatment of any Group found significant. Hence Kushmandachurna with Natural honey or Ushnodakaare effective on Pramehaw.s.r. to Type 2 DM.

Results: With the treatment of 4 weeks , Group A showed dramatic improvements in signs and symptoms. Resolution of Bahumutrata, Mutraavilata, Urine sugar post prandial occurred in about $80 \%$ of patients. Whereas $70 \%$ of patients having reduction in Blood sugar fasting, bold sugar post prandial and urine sugar fastin. In patients of Group B, Blood sugar fasting and post prandial shows good results in 50\%. Cessation of Bahumutrata, Urine sugar fasting \& post prandial occurred in $60 \%$, whereasMutraavilata reduced in 70\%. So use of Kushmandachurna with anupana as Natural honey or Usnodaka shows significant effect. But when compared before and after treatment by applying ' $t$ ' test to parameters, $p>0.001$ hence difference is not significant. Any treatment can use for Prameha

\section{Discussion:-}

\section{KushmandaChurna ${ }^{11,12}$ Madhu(Natural Honey)}

1.Rasa - MadhurMadhura , Kashaya

2.Guna-Laghu, Snigdha, SheetaRuksha, Laghu, Sukshma, Pichhila

3.Virya - SheetaUshana.

4.Vipaka - MadhuraKatu

5. Prabhawa-Medhya

\section{Action of Kushmanda with Madhu-}

In Prameha, Kushmanda may help to treat dhatu-shaithilyadue to its Kapha-pittaharaand Kshariya properties. Its having sheetvirya and kshariya properties act as Bastishodhaka..Kushmamda work as balya in Pamehi patient.KushamndaChurna which possess properties like Vatanulomaka, Trushnanigrahanatridoshaghna, raktapittaprashamanaetc.,due to which nourishment of the tissue elements of Pramehipatients can take place. Kushmanda is described by Rajanighantufor all types of Prameha. Natural honey have sukshma, laghugunadue to this it reaches first tissue of body and goes to most subtle parts e.g. up to Med, mans, majja, raktadidhatu. It is Yogawahi i.e. it enhances the therapeutic effects of drug which are added to it. Honey alleviates all 3 doshas but primarily Kaph because of ushnavirya and katuvipaka.

\section{Action of Kushmanda with Ushnodaka -}

According to Yogaratnakaraushnodaka described as Sadapathya (always good for health). Usnhodaka have kaphaghna ,Medaghna , Vataghna, Amadoshnashak properties. Accrding to Sushrutaushnodaka work as bastishodhak. So if we use Kushmandachurna with ushnodaka it act on tridoshdushti ,dhatugatdushti and important on bastidushti due having laghu, ruksha, sheetaguna and tridoshahara property. According to VagbhatacharyaUshnodak have dipak, pachak, Mutrashohak properties which beneficial to act on vitiated pachakpiita, agnimandya , mutravuddhi in Prameha. 
Dr. Shinde Bhagwat ${ }^{1}$, Inte rnational Journal of Ayurvedic\& Herbal Medicine 7(4) July.-Aug.2017 (2718-2723)

\section{Sampraptibhanga-}

According to Madhavanidanapramehastart with vitiated tridosha. Though in sampraptitridosha mentioned but kaphadoshavitiation shown prominently. We have use KushmandaChurnawith natural honey for prameha. Here both drugs are tridoshhara, so its helpful to balance tridosha. Now if we see saperatedoshdushti of kledakkaph, pachak pitta and saman -apanvayu. First of all in saman and apanvayudushti ,Shitvirya, Kshariya, Bastishodhana, properties of kushmandachurna help to balance them. Due to havingvatanulomaka, trushnanigrahana, Pittashamaka it act as Pachaka. We were used natural honey too, it having agnidipak, easy to digest, yogawahi, pittaghna properties which beneficial to recover pachak pitta dushti. Related to vatadushti both Kushmandachurna and natural honey possessingtridoshahara, kledaghna, bastishodhak properties which act on vitiated samanavata and apanvata and help in balancing them in human body. One more important thing in breakdown of samprapti is Yogawahi and Suksmaguna of natural honey; due to this medicine reaches the first tissue of the body and goes to the most subtle parts. Due to kledotpatti, mutravrudhi, dhatwgnimandya leads to dhatushaithilya; but we are using Kushmandachurna with natural honey which have some of ushna , ruksha, grahi, katu , kashayaras properties to defend dhatushaithilya. On another way Usnhodaka have kaphaghna,Medaghna , Vataghna, Amadoshnashak properties are good remedy for Pramehipatients.

\section{Conclusion :-}

Group A shows highly significant relief in the chief complaints of Prameha when compared within group. They are- Bahumutrata, Mutraavilata, Fasting and Post Prandial Sugar as well as urine. On other hand Group B also shows highly significant result in reducing all signs and symptoms. In Gr A \&B , respective treatment proved to be very effective. But when outcomes compared with each other (Between Gr A \& B), no significant difference found. So we can use any remedy in Prameha.

\section{References :-}

1. whqlibdoc.who.int/hq/1999/WHO_NCD_NCS_99.2.pdf (Accessed Date 8/1/2016 at 12.30pm)

2. http://www.searo.who.int/india/mediacentre/events/2016/en/ (Accessed Date 8/1/2016 at 1.30pm)

3. www.who.int/diabetes/en/(Accessed Date 31/1/2016 at 11.00am)

4. enm.wikipedia.org/wiki/Diabetes-mellitus type 2(Accessed Date 10/2/2016 at 12.30pm)

5. Harrison's Principles of Internal Medicine , Vol. 2, 18th Edition

6. MadhavNidanYidyotioni Hindi Commentary Notes, 13th Edition Vol .1 \&Chowkhamba, Sanskrit Sansthan, Varanasi.7 SarthVagbhat - AnmolPrakashana - Reprint 2007 Vd. Ganesh KrushnaGarde

7. Raja Nighantu -ShriNarahariPandit - ChoukhamabaOrientalia Publication - 2012

8. SushrutSamhita -Atrideva, BhaskarGovindjiGhanekar, LalchandrajiVaidya- MotilalBanarsidass Publisher- 2007 - SutrasthanabVd. Shrilaxmipatishastri -Yogaratnakarara- VidyotiniTika- Reprint 2008- ChoukhambaPrakashana - Purvardha

9. NighantuAdarshaVol 1 -BapalalVaidya - ChoukhambaBharati Academy Publication - 2013

10. Textbook of dravyagunavidnyana - AcharyaPriyavrata Sharma Vol 2 - ChoukhambaBharati Academy -2006 